\title{
Combination of salinomycin and radiation effectively eliminates head and neck squamous cell carcinoma cells in vitro
}

\author{
THOMAS GEHRKE ${ }^{1}$, STEPHAN HACKENBERG ${ }^{1}$, BÜLENT POLAT ${ }^{2}$, GISELA WOHLLEBEN $^{2}$, \\ RUDOLF HAGEN $^{1}$, NORBERT KLEINSASSER ${ }^{1}$ and AGMAL SCHERZAD ${ }^{1}$ \\ Departments of ${ }^{1}$ Otorhinolaryngology, Head and Neck Surgery and ${ }^{2}$ Radiooncology, University Hospital, \\ D-97080 Wuerzburg, Germany
}

Received August 29, 2017; Accepted January 24, 2018

DOI: $10.3892 / o r .2018 .6267$

\begin{abstract}
The antibiotic drug salinomycin has been reported to mediate cancer cell-specific cytotoxicity, especially regarding cancer stem cells. Since salinomycin has also been reported to arrest cancer cells in the G2 phase, it may have possible radiosensitizing effects. Radiotherapy is a common therapeutic strategy for head and neck squamous cell carcinoma (HNSCC). The aim of the present study was to evaluate a possible influence of salinomycin on the radiosensitivity of the HNSCC cell line HLaC-78 in vitro. HLaC-78 cells were incubated with $5 \mu \mathrm{M}$ salinomycin or control medium for $24 \mathrm{~h}$ and then received 5-Gy irradiation. Subsequently, analysis of cell viability, apoptosis, necrosis and motility through an MTT and a colony formation assay, as well as an Annexin V/propidium-iodide test, a consecutive cell count for four days and a scratch assay were conducted. Additionally, interleukin-8 secretion was assessed using ELISA, due to its role in tumor progression and angiogenesis. Combined treatment with salinomycin and radiation revealed a significantly higher reduction of tumor cell viability, proliferation, motility and secretory capacity compared to cells receiving only one of the treatments alone. Therefore, it is postulated that radiation and salinomycin are an effective combination therapy against HNSCC, a hypothesis which warrants further investigation in cell lines, as well as in an animal model.
\end{abstract}

\section{Introduction}

Each year $5 \%$ of all newly diagnosed malignant tumors in the USA, are head and neck squamous cell carcinomas (HNSCCs) (1). Furthermore, at the time of diagnosis, the majority of the patients present with locally advanced-stage disease (2). Thus, the overall 5-year survival rate has not

Correspondence to: Dr Thomas Gehrke, Department of Otorhinolaryngology, Head and Neck Surgery, University Hospital, 11 Josef Schneider Street, D-97080 Wuerzburg, Germany

E-mail: gehrke_t@ukw.de

Key words: salinomycin, radiation, HNSCC, radiosensitizer, HLaC improved significantly since the 1970 s and is currently approximately $60 \%$ (3).

For unresectable HNSCC, combined chemoradiation is the most frequently conducted therapy (4). The cytostatic agent cisplatin was introduced as a radiosensitizing drug in 1979 (5) and is currently the most frequently used radiosensitizer for HNSCC and for the majority of other cancer entities. Another former chemotherapeutic agent, mitomycin $\mathrm{C}$, has also been used for its additive effects with radiation for more than 40 years (6). Both cisplatin and mitomycin $\mathrm{C}$ mainly contribute to the effect of radiation by arresting cancer cells in the $\mathrm{G} 2$ phase (7). In addition, radiation therapy has undergone substantial changes, notably with the introduction of intensitymodulated radio therapy (IMRT), regarding the efficacy and the reduction of therapy-associated morbidity (8). However, locoregional relapse and distant metastases still occur in $40-60 \%$ of the patients treated with primary combined chemoradiation (9). Thus, there is a need for new therapeutic strategies in order to maximize the effects of radiation, while not increasing its side effects.

Salinomycin is a mono-carboxylic polyether antibiotic agent isolated from the bacterium Streptomyces albus (10). Its main use is in veterinary medicine against coccidial parasites in poultry (11). In the last decade, however, accumulating evidence indicates a role for salinomycin as an anticancer drug (12). Out of a vast amount of 16,000 compounds, salinomycin has been identified as the most effective agent in eliminating cancer stem cells (CSCs) and has been demonstrated to be more than 100-fold more effective than paclitaxel (13). These CSCs, whose cell markers have been identified in several HNSCC cell lines as well (14), have been indicated as a possible reason for the failure of conventional cancer treatment $(15,16)$, making salinomycin an interesting candidate as an anticancer drug. Several studies have already elucidated the potential role of salinomycin as a cancerspecific cytotoxic drug. Salinomycin has been demonstrated to effectively eliminate cancer cells of lung (17), breast (18), gastric (19) and myeloic (20) origin in vitro. Scherzed et al (21) also demonstrated a tumor-inhibitory effect of salinomycin on HNSCC cell lines in vitro. In different animal models, this inhibitory effect on tumor cell proliferation and tumor growth was also demonstrated for hepatocellular (22) and nasopharyngeal (23) carcinoma in vivo. The underlying mechanisms 
of this tumor cell cytotoxicity that have been described include an increase in apoptosis via the accumulation of reactive oxygen species (ROS) (24), inhibition of the Wnt/ $\beta$-catenin signaling (20), inhibition of Akt/NF- $\mathrm{B}$ (25) and death receptor-5 upregulation (26).

Apart from the antitumorigenic properties of salinomycin, a more effective tumor elimination effect was demonstrated when combining salinomycin with different cytostatic drugs such as cisplatin (27), paclitaxel (28), gemcitabine (29) and doxorubicin (30). Salinomycin has also been demonstrated to overcome drug resistance in cancer cells, especially regarding cisplatin $(26,31,32)$.

Another major effect of salinomycin has been found to be the mediation of cancer-cell arrest in the $G 2$ phase and the cause of DNA damage $(18,33)$, which is an indicator for a potential use of salinomycin as a sensitizer for radiation therapy. For a breast cancer cell line, the radiosensitizing properties of salinomycin have already been described (33). In contrast other studies, revealed cell cycle arrest in the G0/G1 phase mediated by salinomycin $(26,34)$. For HNSCC, however, data on salinomycin-induced radiosensitizing effects are scarce.

An emerging role in tumor progression is being played by interleukin-8 (IL-8). It has been associated with tumor progression and angiogenesis and its increased expression negatively impacts patient survival $(35,36)$. Furthermore, previous studies have demonstrated a correlation between the antitumor effects of different substances such as simvastatin and celecoxib and a decrease in IL- 8 secretion by the treated cancer cells (37). Hence we decided to include an analysis of IL- 8 secretion into our test assays in the present study.

The aim of the present study was to evaluate the effect of a combination therapy of radiation and salinomycin on an HNSCC cell line in vitro.

\section{Materials and methods}

Cell culture. The HNSCC cell line HLaC-78 was obtained from ECACC (European Collection of Authenticated Cell Cultures; Salisbury, UK). The cells were grown in RPMI-expansion medium (RPMI-EM) consisting of RPMI-1640 medium (Biochrom AG, Berlin, Germany) with $10 \%$ FCS, $100 \mathrm{U} / \mathrm{ml}$ penicillin, $100 \mu \mathrm{g} / \mathrm{ml}$ streptomycin, $1 \%$ sodium pyruvate $(100 \mathrm{mM}$; Biochrom AG) and $1 \%$ non-essential amino acids (100-fold concentration; Biochrom AG). The cells were cultured in culture flasks at $37^{\circ} \mathrm{C}$ with $5 \% \mathrm{CO}_{2}$. The medium was replaced every other day and passaging was performed after reaching $70-80 \%$ confluency by trypsinization, with subsequent washing and seeding in new flasks or treatment wells. The experiments were performed using cells in the exponential growth phase. All experiments were performed using three 'biological replicates' (three fresh cultures on different days from the available stock) and three technical replicates.

3-(4,5-Dimethylthiazol-2-yl)-2,5-diphenyltetrazolium bromide (MTT) assay. After three days of culture, an MTT (SigmaAldrich Chemie GmbH, Taufkirchen, Germany) colorimetric staining method was performed according to Mosmann (38) to determine cell viability. The cells were seeded at 10,000 cells/well in a 12 -well plate. All wells were incubated with $1 \mathrm{ml} \mathrm{MTT}(1 \mathrm{mg} / \mathrm{ml})$ for $5 \mathrm{~h}$ at $37^{\circ} \mathrm{C}$ and $5 \% \mathrm{CO}_{2}$. MTT was then removed and $1 \mathrm{ml}$ isopropanol was added, followed by another incubation period of $1 \mathrm{~h}$ at $37^{\circ} \mathrm{C}$ and $5 \% \mathrm{CO}_{2}$. Assessement of the color conversion of the blue formazan dye was performed using a multi-plate reader (Titertek Multiskan PLUS MK II; Thermo Fisher Scientific, Inc., Darmstadt, Germany) at a wavelength of $570 \mathrm{~nm}$. Initially, the doses of salinomycin and radiation required for the present study were evaluated by the MTT assay, resulting in $5 \mu \mathrm{M} / \mathrm{ml}$ salinomycin and a radiation dose of 5 Gy (Fig. 1).

Radiation of cell cultures. To examine the effect of irradiation, the HLaC-78 cells were irradiated $24 \mathrm{~h}$ after onset of the cultures at a dose of 5 Gy using a $6 \mathrm{MV}$ linear accelerator (Siemens, Concord, CA, USA) at a dose rate of $2 \mathrm{~Gy} / \mathrm{min}$.

Exposure to salinomycin and radiation. HLaC-78 cells were treated with $5 \mu \mathrm{M} / \mathrm{ml}$ salinomycin (Sigma-Aldrich, St. Louis, MO, USA), 5 Gy radiation or the combination of both. Incubation with salinomycin was conducted $8 \mathrm{~h}$ before performing radiation in the combination group. Analytical assays were performed after $24 \mathrm{~h}$ of incubation.

Colony formation assay. The HLaC-78 cells were seeded into 6 -well plates at a concentration of $2.5 \times 10^{3}$ cells/well in triplicate. The well plates were defined for cells treated with salinomycin, radiation or the combination of both. HLaC-78 cells cultivated in RPMI-EM served as the control. The cells were incubated for 14 days. After two weeks, the well plates were stained with crystal violet and the colonies were counted manually.

Cell count. A total of $5 \times 10^{4}$ cells were incubated in DMEM-EM at $37^{\circ} \mathrm{C}$ with $5 \% \mathrm{CO}_{2}$ for 4 days, while electronically evaluating the cell number and cell viability each day using $\mathrm{CASY}^{\circledR}$ Technology (Innovatis AG, Reutlingen, Germany). Only cells labeled viable by electronic counting were included in the cell counting analysis.

Annexin V/propidium iodide (PI) test. The BD Pharmingen Annexin V-APC kit (BD Biosciences, Heidelberg, Germany) was used to evaluate apoptosis. After 3 days of co-culture, cells in suspension and adherent cells were harvested, then washed twice with phosphate-buffered saline (PBS) and resuspended in 1:10 binding buffer [0.1 M HEPES (pH 7.4; Sigma-Aldrich), 1.4 M $\mathrm{NaCl}$ and $25 \mathrm{mM} \mathrm{CaCl}_{2}$ ] at a concentration of $1 \times 10^{6}$ cells $/ \mathrm{ml}$. Aliquots of this cell suspension $\left(100 \mu \mathrm{l} ; 1 \times 10^{5}\right.$ cells) were then transferred to a $5 \mathrm{ml}$ culture tube. PI $(5 \mu \mathrm{l})$ and Annexin V-APC $(5 \mu \mathrm{l})$ were added to each aliquot. After $15 \mathrm{~min}$ of incubation at room temperature in the dark, the cells were resuspended with $400 \mu 1$ 1:10 binding buffer. A FACSCanto flow cytometer was used to analyze the samples with BD FACSDiva version 5.0.3 software (both from BD Biosciences). Only cells with damaged membranes were stained by PI.

Scratch assay. A scratch assay was used to analyze cell migration capability. HLaC-78 cells $\left(1 \times 10^{5}\right.$ cells $\left./ \mathrm{ml}\right)$ were cultivated in a 12 -well round-bottom plate at $37^{\circ} \mathrm{C}$ and $5 \%$ $\mathrm{CO}_{2}$. After $24 \mathrm{~h}$, a straight-line wound was induced with a sterile $1 \mathrm{ml}$ pipette tip. Subsequently, the culture plates were washed with PBS and images were captured (day 0) with a Leica DMI4000 B Inverted Microscope at x40 magnification 


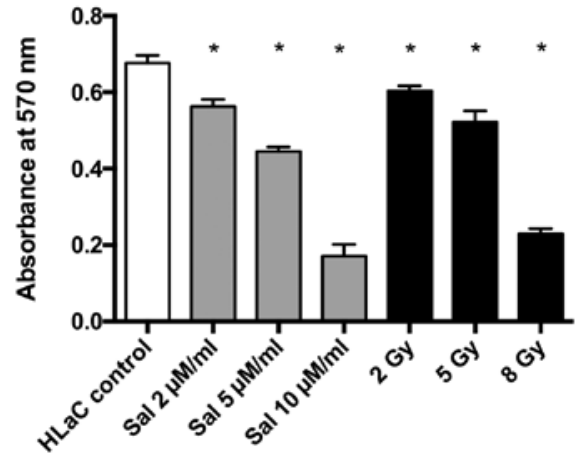

Figure 1. Determination of the doses of salinomycin and radiation by MTT assay. Salinomycin $(5 \mu \mathrm{M} / \mathrm{ml})$ and $5 \mathrm{~Gy}$ of radiation were chosen for the experiments consequently. ${ }^{*} \mathrm{P}<0.05$ compared to the control group; Sal, Salinomycin; nm, nanometer; Gy, gray.

(Leica Microsystems GmbH, Wetzlar, Germany). The cells were then incubated for a further $24 \mathrm{~h}$ at $37^{\circ} \mathrm{C}$ with $5 \% \mathrm{CO}_{2}$, before images of the plates were captured (day 1) and the percentage of the wound closure was evaluated. This was repeated after another $24 \mathrm{~h}$ of incubation (day 2). The calculation of the area of the wound closure was investigated using ImageJ software (version $1.43 \mathrm{u}$, open source product) at days 0,1 and 2 .

Cell cycle analysis. To analyze the effect of salinomycin and radiation on the cell cycle of HLaC-78 cells, $1 \times 10^{5}$ cells were cultivated in 12-well plates in triplicate. Following a $48 \mathrm{~h}$ period, HLaC-78 cells were trypsinized and washed twice with cold PBS. The cells were then fixed in $1 \mathrm{ml}$ of $70 \%$ cold ethanol in test tubes and incubated for $2 \mathrm{~h}$ at $4^{\circ} \mathrm{C}$ in the dark. After incubation, the cells were centrifuged at $500 \mathrm{~g}$ for $5 \mathrm{~min}$ at $4^{\circ} \mathrm{C}$ and resuspended in $500 \mu \mathrm{l} \mathrm{PI}$ (BD Biosciences). After another incubation at $4^{\circ} \mathrm{C}$ in the dark for $15 \mathrm{~min}$, the cells were analyzed with flow cytometry within $1 \mathrm{~h}$. HLaC-78 cells cultivated in RPMI-EM served as the control.

IL-8 ELISA. For determining the secretion of IL-8, the supernatants were collected (centrifugation, $150 \mathrm{x} \mathrm{g}$ for $5 \mathrm{~min}$ at $37^{\circ} \mathrm{C}$ ) after 3 days of co-culture and stored at $-20^{\circ} \mathrm{C}$ in sterile tubes until further use. RPMI-EM served as the control. The Human IL-8 ELISA kit (cat. no. 950.050.192; Diaclone SAS, Besançon, France) was used and the experiments were performed in duplicate. The ELISA plate was read at $450 \mathrm{~nm}$ (Titertek Multiskan PLUS MK II; Thermo Fisher Scientific, Inc.). The concentrations of IL- 8 were determined by constructing a standard curve using recombinant IL-8.

Statistical analysis. The data collected were transferred to standard spreadsheets and statistically analyzed using GraphPad Prism software (version 6.0; GraphPad Software, Inc., La Jolla, CA, USA). Data are presented as the mean \pm standard deviation of three experiments, unless otherwise stated. The Gaussian distribution was tested by first column analysis. One-way or (to include time-dependency for cell counting) two-way analysis of variance (ANOVA) followed by Tukey's multiple comparison test was used. Additionally, multiplicity adjusted $\mathrm{P}$-values were determined. $\mathrm{P}<0.05$ was considered to indicate a statistically significant difference.

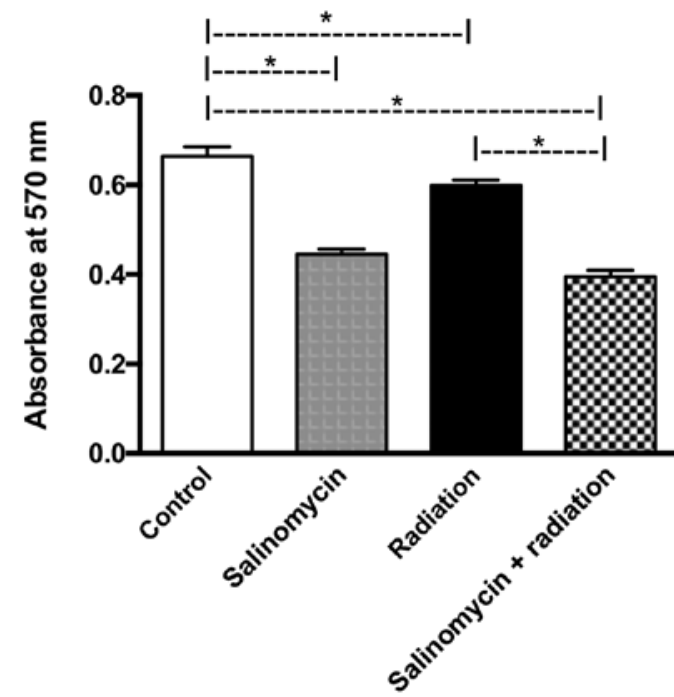

Figure 2. MTT assay. Treatment by salinomycin, radiation and the combination therapy decreased tumor cell viability compared to the control group $(\mathrm{P}<0.05$ each). Combination therapy was more effective than radiation alone $(\mathrm{P}<0.005)$, but not in comparison to salinomycin alone $(\mathrm{P}>0.05)$. nm, nanometer; ${ }^{*} \mathrm{P}<0.05$.

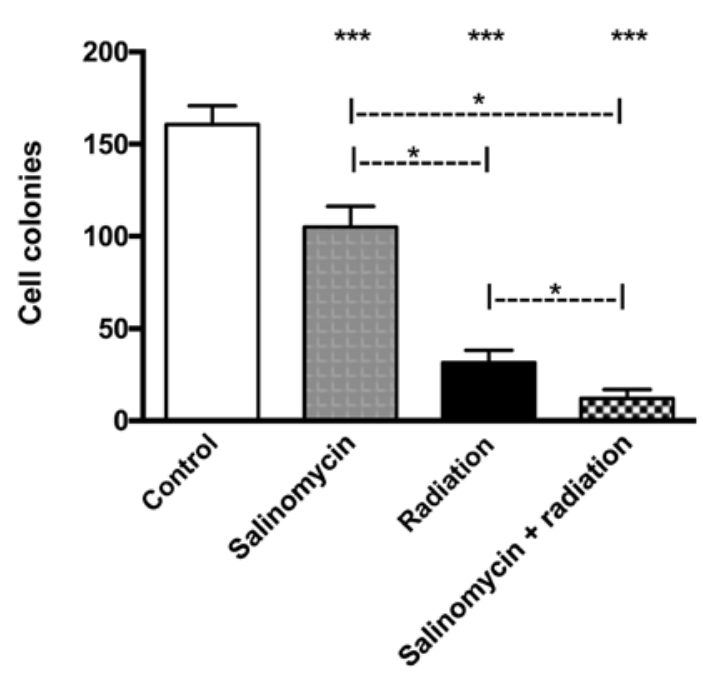

Figure 3. Colony formation assay. All three therapeutic groups exhibited less colony forming than the control group (each $\mathrm{P}<0.05$, indicated by 3 asterisks). While radiation was more effective than salinomycin $(\mathrm{P}<0.05)$, the combination therapy reduced colony forming significantly more than salinomycin or radiation alone $(\mathrm{P}<0.05$ for both $) ;{ }^{*} \mathrm{P}<0.05$.

\section{Results}

MTT assay. The MTT assay revealed a significant reduction of tumor cell viability for treatment with salinomycin $(\mathrm{P}<0.05)$ and radiation alone $(\mathrm{P}<0.05)$ as well as for the combination therapy $(\mathrm{P}<0.05)$. The combination treatment did not exhibit a more significant effect than that of salinomycin alone $(\mathrm{P}>0.05)$, but it was significant compared to radiation alone $(\mathrm{P}<0.05)$ (Fig. 2).

Colony formation assay. Salinomycin and radiation alone as well as the combination of both led to a significantly reduced amount of cell colonies after 14 days $(\mathrm{P}=0.0001$ for all). The combination therapy also proved to be significantly more effective than salinomycin $(\mathrm{P}=0.0001)$ or radiation $(\mathrm{P}=0.0039)$ alone (Fig. 3). 


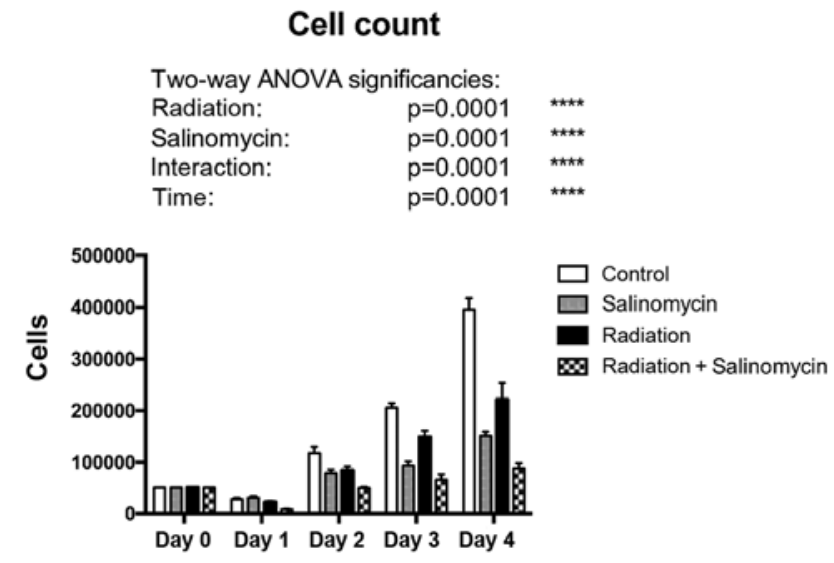

Figure 4. Consecutive cell counting. During the course of four days, salinomycin and radiation alone as well as the combination of both significantly reduced tumor cell proliferation $(\mathrm{P}<0.05$ for each). Two-way ANOVA revealed significances for each therapy alone, the interaction of both as well as time as a factor in it. ${ }^{* * * *}$ Indicating high significance.

\section{Vitality in cell count}

$\begin{array}{lr}\text { Two-way ANOVA significancies: } \\ \text { Radiation: } & \mathrm{p}=0.0001 \\ \text { Salinomycin: } & \mathrm{p}=0.0001 \\ \text { Interaction: } & \mathrm{p}=0.0001 \\ \text { Time: } & \mathrm{p}=0.0001\end{array}$

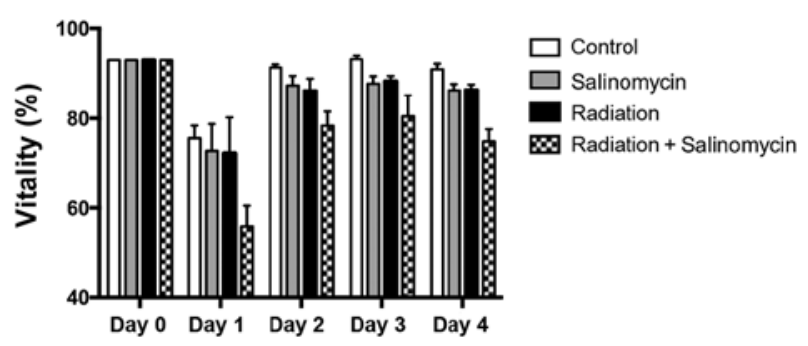

Figure 5. Cell vitality assessed during cell count. After an initial decline, the vitality of tumor cells increased with time, but was reduced in all therapeutic groups compared to the control group. Two-way ANOVA demonstrated significances for salinomycin, radiation, the interaction of both therapies as well as time as a factor $(\mathrm{P}<0.05$ for each).

Cell count. After 4 days of culture, there was a significantly slower cell proliferation when treated with salinomycin $(\mathrm{P}=0.0001)$ or radiation $(\mathrm{P}=0.0001)$ alone, but upon receiving combined treatment, the effect was significantly augmented
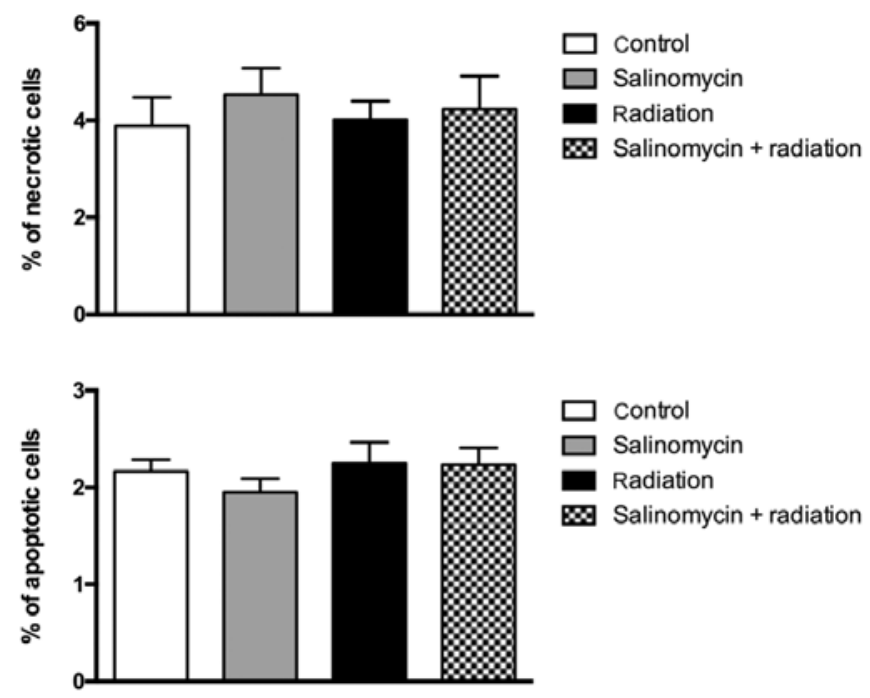

Figure 7. Statistical analysis of the Annexin/propidium-iodide assay. The upper graph demonstrated the percentage of necrotic cells, while the lower one demonstrated the percentage of apoptotic cells in flow cytometry. No statistically significant differences could be demonstrated.

$(\mathrm{P}=0.0001)$ (Fig. 4). Cell vitality was assessed in the same process as cell counting. Following an initial decline, there was an increase over time, which was lower for all therapeutic groups compared to the control group $(\mathrm{P}=0.0001$ for salinomycin, radiation and combined treatment) (Fig. 5).

Annexin VIPI test. There was a general trend for salinomycin to increase the percentage of necrotic cells and for radiation to increase the percentage of apoptotic cells (Fig. 6), yet this was not statistically significant (Fig. 7). In combination therapy, there were higher percentages for both necrotic and apoptotic cells, but they also did not reach a statistical significance (Fig. 7).

Scratch assay. Both radiation alone $(\mathrm{P}=0.0338)$ and combination therapy $(\mathrm{P}=0.0001)$ increased the cell-free area $48 \mathrm{~h}$ after the straight-line wound was applied to the cultured cells compared to the control group, while salinomycin alone did not $(\mathrm{P}=0.1309)$ (Fig. 8). The combined treatment led to a further increase of this effect compared to salinomycin and radiation alone $(\mathrm{P}=0.0001$ for both), indicating a reduced tumor cell motility. Between salinomycin and radiation alone, no statistically significant difference was observed $(\mathrm{P}=0.9014)$.
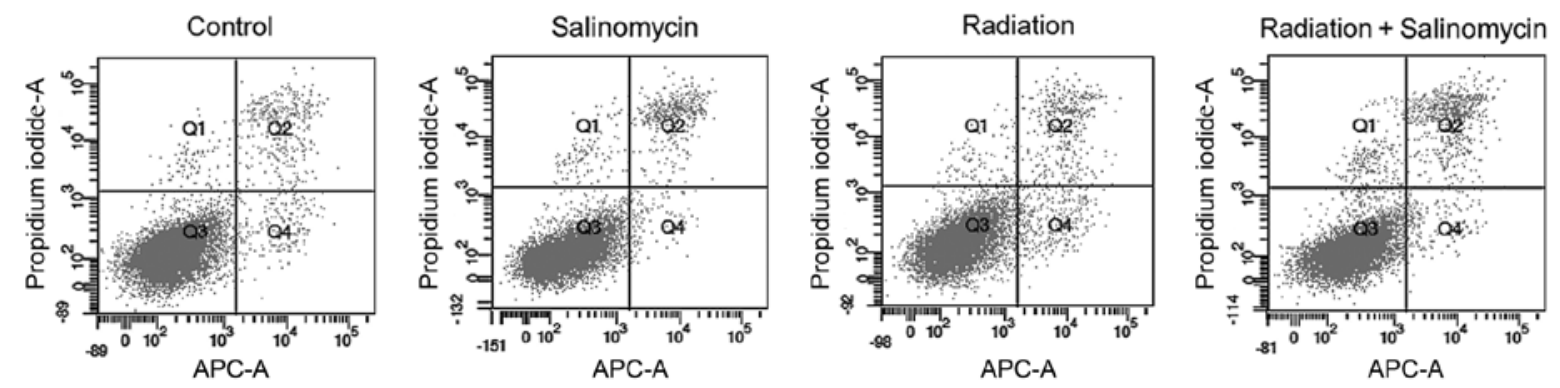

Figure 6. Annexin/propidium iodide assay. No statistically significant differences between the 4 groups in terms of necrosis or apoptosis could be demonstrated (data not shown). Q1, damaged cells; Q2, necrotic cells; Q3, viable cells; Q4, apoptotic cells; APC-A, allophycocyanin-A. 


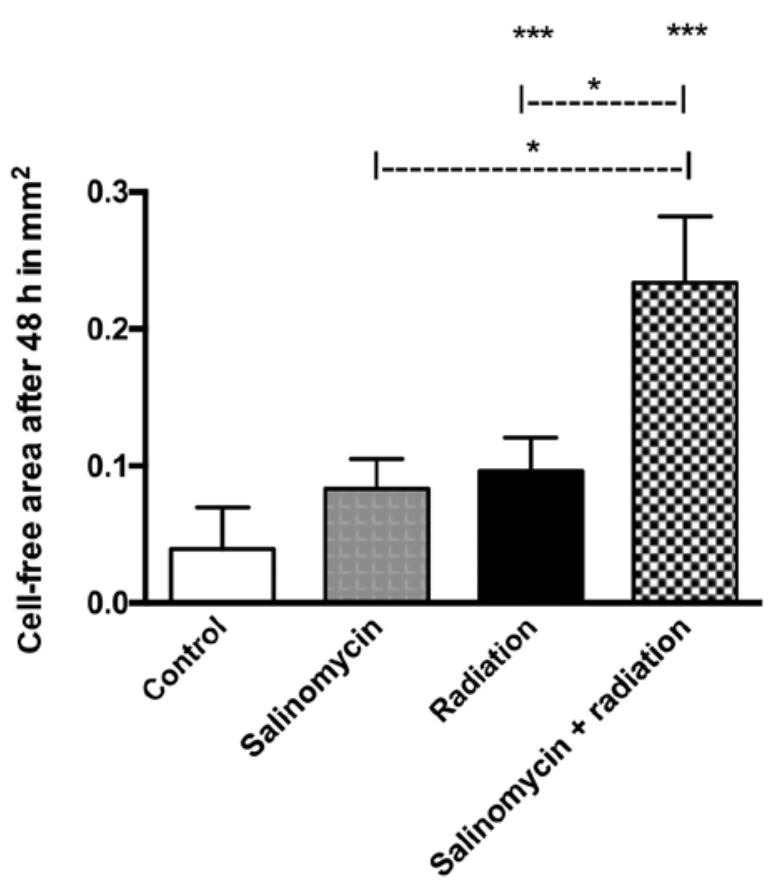

Figure 8. Scratch assay. Radiation and the combination therapy led to a significant increase in cell-free area after $48 \mathrm{~h}(\mathrm{P}<0.05$, indicated by 3 asterisks) compared to the control group. Combination therapy also proved to decrease tumor cell motility in significantly higher levels than salinomycin or radiation alone $\left(\mathrm{P}<0.05\right.$ for both). ${ }^{*} \mathrm{P}<0.05$.

Cell cycle analysis. The flow cytometric cell cycle analysis revealed a rising number of cells in the G0/G1 phase after the addition of salinomycin, while after radiation the number of cells in the G2 phase was increased. When used in combination, both a G0/G1 arrest as well as a G2 arrest were observed (Fig. 9).

IL-8 ELISA. Salinomycin and radiation alone as well as the combination of both reduced the amount of IL-8 secretion of the tumor cells $(\mathrm{P}=0.0001, \mathrm{P}=0.0004$ and $\mathrm{P}=0.0001$, respectively). Salinomycin alone was significantly more effective in this regard than radiation alone $(\mathrm{P}=0.0001)$. The combination therapy proved to reduce IL-8 more effectively than radiation alone $(\mathrm{P}=0.0001)$, but not compared to salinomycin alone $(\mathrm{P}=0.1031)$ (Fig. 10).
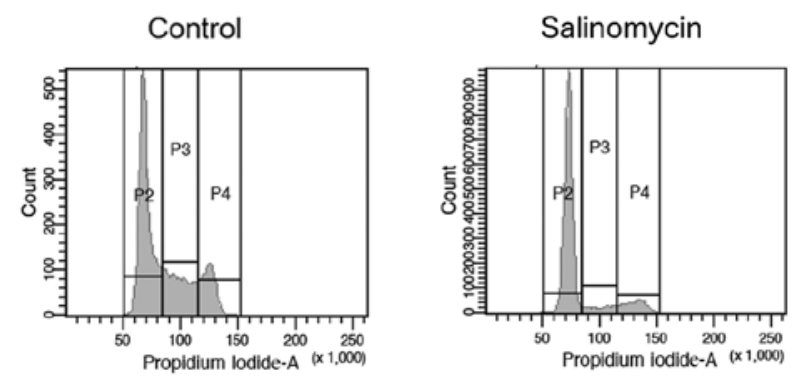

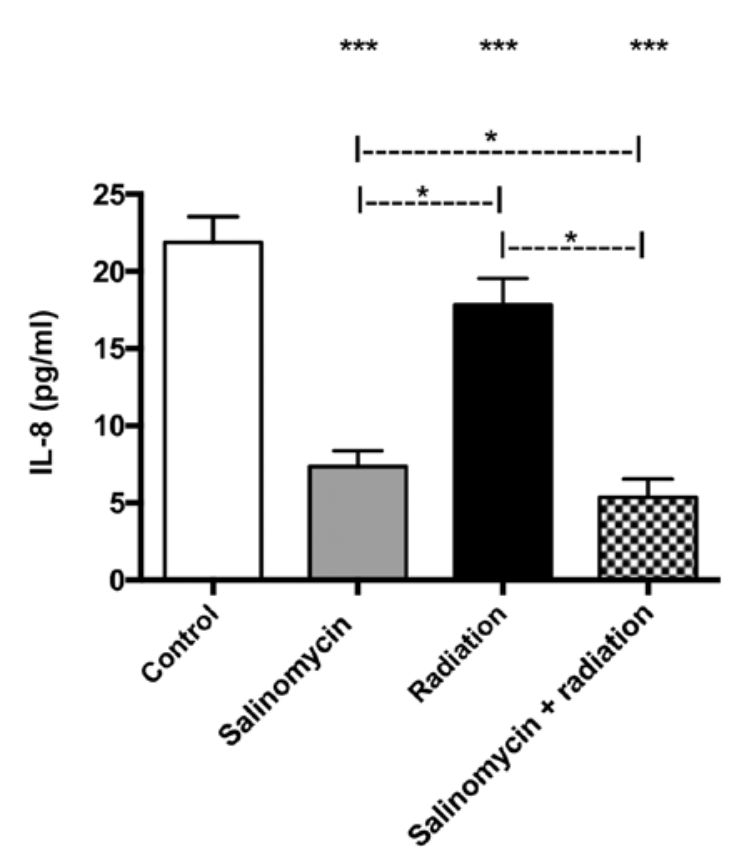

Figure 10. IL-8 ELISA. In all 3 therapeutic groups a decrease in the amount of IL-8 ( $\mathrm{P}<0.05$, indicated by 3 asterisks) was observed. While salinomycin proved to be more effective therein than radiation $(\mathrm{P}<0.05)$, the combination therapy led to significantly lower levels of IL-8 than salinomycin or radiation alone ( $\mathrm{P}<0.05$ for both). ${ }^{\mathrm{P}} \mathrm{P}<0.05$; IL-8, interleukin- 8 .

\section{Discussion}

The aim of the present study was to investigate the effects of a combination therapy of salinomycin and radiation on a HNSCC cell line in vitro. Although many advances regarding the therapy of HNSCC have been made in the last decades, the overall survival rates are still not satisfying (3). The development of tumor cell resistance to radiotherapy (39) or chemotherapy (40) plays a key role in this regard. The emergence of immunotherapy as an important keystone in cancer therapy during the last decade has demonstrated tremendous results for various tumor entities $(41,42)$. For HNSCC, however, immunotherapy is only at its dawn and the results thus far cannot reach up to those of melanomas or hematologic neoplasms (43). Whether this is due to HNSCC not being highly immunogenic compared to other entities remains to be verified (44).

Figure 9. Cell cycle analysis. Treatment by salinomycin increased the number of cells in the G1 phase, while radiation increased the number of cells in the G2 phase. In combination therapy, both an increase in the G1 and the G2 phase can be seen. P2, cells in the G0/G1 phase; P3, cells in S phase; P4, cells in G2 phase. 
Lately, the existence of CSCs as a subpopulation of tumor cells has found a broad consensus $(45,46)$. These CSCs have been observed in a multitude of tissues $(14,47)$ and have already been revealed to be a possible factor for therapeutic failure in clinical studies $(48,49)$. They have been demonstrated to possess numerous intrinsic mechanisms of resistance to conventional chemotherapeutic drugs as well as novel tumor-targeted drugs. Among these mechanisms are the activation of the Wnt/ $\beta$-catenin signaling (50), the amplified checkpoint activation (51), an expression of the ATP-binding cassette (ABC) drug transporters (52), an activation of the Hedgehog and Notch signaling pathways (53) and a metabolic alteration with preference for hypoxia (54). They have also been demonstrated to possess and to promote radioresistance (55), possibly through a radiation-induced conversion of cancer cells to CSCs (56). Several HNSCC cell lines have also been revealed to possess stem cell markers such as CD44 (14). Hence, there is a need for drugs targeting CSCs as well as regular tumor cells.

Salinomycin, used as a veterinary anti-microbiotic drug for more than 40 years, was first revealed to be an effective agent against CSC in 2009 (13). It was demonstrated that the application of salinomycin not only eliminated CSCs of different tumor tissues $(57,58)$, but it could also efficiently kill regular tumor cells (59). This included human cancer cells displaying different mechanisms of drug and apoptosis resistance (59) as well as ABC-transporter-mediated multidrug resistance (60). In addition, treatment with salinomycin prevented radioresistance in cancer cells (33). Therefore, salinomycin is a primary target of interest for new substances able to counteract the resistance to radiation or medical tumor therapies.

In the present study, salinomycin as well as radiation alone exhibited a significant reduction of tumor cell viability and proliferation. While radiation proved to be more efficient in the more time-dependent colony formation assay, the more short-termed tests like the MTT assay and the cell counting revealed a higher reduction of cell viability and proliferation by salinomycin. This confirmed previous data by Wu et al (23) stating an effect of salinomycin on differentiated HNSCC cells in addition to targeting CSCs. The combination of salinomycin and radiation demonstrated significantly better results than each therapy alone, which was already observed for a nasopharyngeal cell line $(61,62)$, thus confirming these effects in the laryngeal carcinoma cell line. The results from the cell counting and colony formation assay furthermore indicated a prolonged effect of salinomycin quite some time after its onetime application.

In the present study, salinomycin appeared to mostly increase necrosis rather than apoptosis, even if this did not reach statistical significance. In most studies an increase in apoptosis through salinomycin via the mito + chondrial pathway of apoptosis (24) or a generation of reactive oxygen species (ROS) (63) was reported, while an induction of non-apoptotic cell deaths (64) was rarely observed. Since salinomycin interferes with transmembrane $\mathrm{K}^{+}$potential and promotes the efflux of $\mathrm{K}^{+}$from mitochondria and cytoplasm, this could be another possible mechanism of cytotoxicity, which could be an explanation for the high efficiency in the MTT assay (65). However, most apoptotic and non-apoptotic mechanisms mediated by salinomycin remain unknown and there appears to be a great variance among the different types of tissue the cancer cells are derived from (12).

The cell cycle analysis revealed a G2-arrest by radiation, as was expected. Salinomycin, on the other hand, demonstrated a profound arrest of the tumor cells in the G0/G1 phase. In literature, there are differing results for salinomycin interfering in the cell cycle. Some studies reported a G2-arrest on cancer cells, most notably those who also reported a radiosensitizing effect of salinomycin $(33,62)$. Others demonstrated a G0/G1 arrest (34) or even a prevention of G2 arrest (64). To be a candidate as a radiosensitizer such as cisplatin, a G2 arrest would be highly valuable. As such, for the cell line used in the present study no G2 arrest could be demonstrated, rendering its use as a classical radiosensitizer improbable. Nonetheless, a concurrent arrest in the G0/G1 phase via salinomycin and in the $\mathrm{G} 2$-phase via radiation could be a beneficial additive effect in tumor therapy.

The scratch migration assay revealed a similar inhibition of tumor cell motility by salinomycin or radiation alone. In combination therapy, however, the cell-free surface after $48 \mathrm{~h}$ was significantly higher than in each therapy alone. Information on the effect of salinomycin on tumor cell motility is scarce in literature. For mesenchymal derived stem cells (MSC), an inhibition of migrational capabilities by salinomycin was already demonstrated (66). Sun et al (67) reported on attenuated liver cancer stem cell motility by enhancing cell stiffness and increasing F-actin formation via the FAK-ERK1/2 signalling pathway mediated by salinomycin. Kopp et al (68) demonstrated reduced migration and thereby reduced metastasis formation with salinomycin for breast and lung cancer cell lines. Therefore, salinomycin appeared to have an additional effect on the migrational capabilities of cancer cells.

In the present study, an IL-8 ELISA was included into the test array. IL-8, one of the ELR ${ }^{+}$CXC family of chemokines, is a potent pro-angiogenic factor and its expression is associated with angiogenesis, tumor progression and survival in patients with cancer $(35,36)$. For other substances such as simvastatin or celecoxib, which have been recently tested for tumortoxic properties as well, a decrease in IL-8 secretion by the cancer cells as part of the antitumor effects could be demonstrated (37). For salinomycin, only a single study contained data on IL-8, reporting on an elevated IL-8 secretion when treating human nasal mucosa and peripheral blood lymphocytes with $5 \mu \mathrm{M}$ salinomycin (69). For cancer cells, no data on the changes of IL- 8 secretion are available in the literature. In the present study, a significant reduction of IL- 8 secretion following treatment with salinomycin compared to radiation alone and an additional effect when combining salinomycin and radiation was observed. Since IL-8 is a prominent factor in angiogenesis and progression in cancer, this could be another mechanism contributing to the antitumor effects of salinomycin. While the decrease in IL-8 is partly attributed to the concurrent decrease in cell number in the respective groups, the amount of IL-8 reduction cannot be completely explained hereby and suggests an additional, underlying salinomycin-dependent mechanism.

In conclusion, salinomycin and radiation effectively eliminated HNSCC cells in vitro, with the combination of salinomycin and radiation being more efficient than each of the therapies alone. The underlying mechanisms involved a 
reduction in cell viability and proliferation, reduced tumor-cell motility and migration, cell cycle arrest in the G0/G1 phase and decreased secretion of IL-8. Although salinomycin may not be a classical radiosensitizer, the many different mechanisms by which it affects tumor cells and especially CSCs, justify further investigation on the possible role of salinomycin as an additive medical therapy for cancer treatment.

\section{Competing interests}

The authors declare that they have no competing interests.

\section{References}

1. Siegel RL, Miller KD and Jemal A: Cancer statistics, 2016. CA Cancer J Clin 66: 7-30, 2016.

2. Seiwert TY and Cohen EE: State-of-the-art management of locally advanced head and neck cancer. Br J Cancer 92: 13411348,2005

3. Miller KD, Siegel RL, Lin CC, Mariotto AB, Kramer JL, Rowland JH, Stein KD, Alteri R and Jemal A: Cancer treatment and survivorship statistics, 2016. CA Cancer J Clin 66: 271-289, 2016.

4. Vermorken JB, Remenar E, van Herpen C, Gorlia T, Mesia R, Degardin M, Stewart JS, Jelic S, Betka J, Preiss JH, et al: Cisplatin, fluorouracil, and docetaxel in unresectable head and neck cancer. N Engl J Med 357: 1695-1704, 2007.

5. Douple EB and Richmond RC: A review of platinum complex biochemistry suggests a rationale for combined platinumradiotherapy. Int J Radiat Oncol Biol Phys 5: 1335-1339, 1979.

6. Rockwell S and Kennedy KA: Combination therapy with radiation and mitomycin C: Preliminary results with EMT6 tumor cells in vitro and in vivo. Int J Radiat Oncol Biol Phys 5: 1673$1676,1979$.

7. Wennerberg J, Alm P, Biörklund A, Killander D, Långström E and Tropé C: Cell cycle perturbations in heterotransplanted squamous-cell carcinoma of the head and neck after mitomycin C and cisplatin treatment. Int J Cancer 33: 213-222, 1984.

8. Gomez-Millan J, Fernández JR and Medina Carmona JA: Current status of IMRT in head and neck cancer. Rep Pract Oncol Radiother 18: 371-375, 2013.

9. Prestwich RJ, Öksüz DÇ, Dyker K, Coyle C and Şen M: Feasibility and efficacy of induction docetaxel, cisplatin, and 5-fluorouracil chemotherapy combined with cisplatin concurrent chemoradiotherapy for nonmetastatic Stage IV head-and-neck squamous cell carcinomas. Int J Radiat Oncol Biol Phys 81: e237243, 2011.

10. Miyazaki Y, Shibuya M, Sugawara H, Kawaguchi O and Hirsoe C: Salinomycin, a new polyether antibiotic. J Antibiot 27: 814-821, 1974

11. Danforth HD, Ruff MD, Reid WM and Miller RL: Anticoccidial activity of salinomycin in battery raised broiler chickens. Poult Sci 56: 926-932, 1977.

12. Naujokat C, Fuchs D and Opelz G: Salinomycin in cancer: A new mission for an old agent. Mol Med Rep 3: 555-559, 2010.

13. Gupta PB, Onder TT, Jiang G, Tao K, Kuperwasser C, Weinberg RA and Lander ES: Identification of selective inhibitors of cancer stem cells by high-throughput screening. Cell 138: 645-659, 2009.

14. Pries R, Wittkopf N, Hasselbacher K and Wollenberg B: Constitutive expression of the potential stem cell marker CD44 in permanent HNSCC cell lines. HNO 56: 461-466, 2008 (In German).

15. Boman BM and Wicha MS: Cancer stem cells: A step toward the cure. J Clin Oncol 26: 2795-2799, 2008.

16. Davis SJ, Divi V, Owen JH, Bradford CR, Carey TE, Papagerakis S and Prince ME: Metastatic potential of cancer stem cells in head and neck squamous cell carcinoma. Arch Otolaryngol Head Neck Surg 136: 1260-1266, 2010.

17. Arafat K, Iratni R, Takahashi T, Parekh K, Al Dhaheri Y, Adrian TE and Attoub S: Inhibitory effects of salinomycin on cell survival, colony growth, migration, and invasion of human non-small cell lung cancer A549 and LNM35: Involvement of NAG-1. PLoS One 8: e66931, 2013.
18. Al Dhaheri Y,Attoub S, Arafat K, Abuqamar S, Eid A, Al Faresi N and Iratni R: Salinomycin induces apoptosis and senescence in breast cancer: Upregulation of p21, downregulation of survivin and histone $\mathrm{H} 3$ and $\mathrm{H} 4$ hyperacetylation. Biochim Biophys Acta 1830: 3121-3135, 2013

19. Zhi QM, Chen XH, Ji J, Zhang JN, Li JF, Cai Q, Liu BY, Gu QL, Zhu ZG and Yu YY: Salinomycin can effectively kill ALDH ${ }^{\text {high }}$ stem-like cells on gastric cancer. Biomed Pharmacother 65: 509-515, 2011.

20. Lu D, Choi MY, Yu J, Castro JE, Kipps TJ and Carson DA: Salinomycin inhibits Wnt signaling and selectively induces apoptosis in chronic lymphocytic leukemia cells. Proc Natl Acad Sci USA 108: 13253-13257, 2011.

21. Scherzed A, Hackenberg S, Froelich K, Rak K, Ginzkey C, Hagen R, Schendzielorz P and Kleinsasser N: Effects of salinomycin and CGP37157 on head and neck squamous cell carcinoma cell lines in vitro. Mol Med Rep 12: 4455-4461, 2015.

22. Wang F, He L, Dai WQ, Xu YP, Wu D, Lin CL, Wu SM, Cheng P, Zhang Y, Shen M, et al: Salinomycin inhibits proliferation and induces apoptosis of human hepatocellular carcinoma cells in vitro and in vivo. PLoS One 7: e50638, 2012.

23. Wu D, Zhang Y, Huang J, Fan Z, Shi F and Wang S: Salinomycin inhibits proliferation and induces apoptosis of human nasopharyngeal carcinoma cell in vitro and suppresses tumor growth in vivo. Biochem Biophys Res Commun 443: 712-717, 2014.

24. Kim KY, Yu SN, Lee SY, Chun SS, Choi YL, Park YM, Song CS, Chatterjee B and Ahn SC: Salinomycin-induced apoptosis of human prostate cancer cells due to accumulated reactive oxygen species and mitochondrial membrane depolarization. Biochem Biophys Res Commun 413: 80-86, 2011.

25. Parajuli B, Lee HG, Kwon SH, Cha SD, Shin SJ, Lee GH, Bae I and Cho CH: Salinomycin inhibits Akt/NF-kappaB and induces apoptosis in cisplatin resistant ovarian cancer cells. Cancer Epidemiol 37: 512-517, 2013.

26. Parajuli B, Shin SJ, Kwon SH, Cha SD, Chung R, Park WJ, Lee HG and Cho CH: Salinomycin induces apoptosis via death receptor-5 up-regulation in cisplatin-resistant ovarian cancer cells. Anticancer Res 33: 1457-1462, 2013.

27. Ko JC, Zheng HY, Chen WC, Peng YS, Wu CH, Wei CL, Chen JC and Lin YW: Salinomycin enhances cisplatin-induced cytotoxicity in human lung cancer cells via down-regulation of AKT-dependent thymidylate synthase expression. Biochem Pharmacol 122: 90-98, 2016.

28. Muntimadugu E, Kumar R, Saladi S, Rafeeqi TA and Khan W: CD44 targeted chemotherapy for co-eradication of breast cancer stem cells and cancer cells using polymeric nanoparticles of salinomycin and paclitaxel. Colloids Surf B Biointerfaces 143: 532-546, 2016

29. Zhang GN, Liang Y, Zhou LJ, Chen SP, Chen G, Zhang TP, Kang $\mathrm{T}$ and Zhao YP: Combination of salinomycin and gemcitabine eliminates pancreatic cancer cells. Cancer Lett 313: 137-144, 2011.

30. Kim JH, Chae M, Kim WK, Kim YJ, Kang HS, Kim HS and Yoon S: Salinomycin sensitizes cancer cells to the effects of doxorubicin and etoposide treatment by increasing DNA damage and reducing p21 protein. Br J Pharmacol 162: 773-784, 2011.

31. Zhang B, Wang X, Cai F, Chen W, Loesch U and Zhong XY: Antitumor properties of salinomycin on cisplatin-resistant human ovarian cancer cells in vitro and in vivo: Involvement of p38 MAPK activation. Oncol Rep 29: 1371-1378, 2013.

32. Zhou J, Li P, Xue X, He S, Kuang Y, Zhao H, Chen S, Zhi Q and Guo X: Salinomycin induces apoptosis in cisplatin-resistant colorectal cancer cells by accumulation of reactive oxygen species. Toxicol Lett 222: 139-145, 2013.

33. Kim WK, Kim JH, Yoon K, Kim S, Ro J, Kang HS and Yoon S: Salinomycin, a p-glycoprotein inhibitor, sensitizes radiationtreated cancer cells by increasing DNA damage and inducing G2 arrest. Invest New Drugs 30: 1311-1318, 2012.

34. Zhao SJ, Wang XJ, Wu QJ, Liu C, Li DW, Fu XT, Zhang HF, Shao LR, Sun JY, Sun BL, et al: Induction of G1 cell cycle arrest in human glioma cells by salinomycin through triggering ROS-mediated DNA damage in vitro and in vivo. Neurochem Res 42: 997-1005, 2017.

35. Masuya D, Huang C, Liu D, Kameyama K, Hayashi E, Yamauchi A, Kobayashi S, Haba R and Yokomise H: The intratumoral expression of vascular endothelial growth factor and interleukin-8 associated with angiogenesis in nonsmall cell lung carcinoma patients. Cancer 92: 2628-2638, 2001. 
36. Yuan A, Yang PC, Yu CJ, Chen WJ, Lin FY, Kuo SH and Luh KT: Interleukin-8 messenger ribonucleic acid expression correlates with tumor progression, tumor angiogenesis, patient survival, and timing of relapse in non-small-cell lung cancer. Am J Respir Crit Care Med 162: 1957-1963, 2000.

37. Gehrke T, Scherzad A, Hackenberg S, Ickrath P, Schendzielorz P, Hagen R and Kleinsasser N: Additive antitumor effects of celecoxib and simvastatin on head and neck squamous cell carcinoma in vitro. Int J Oncol 51: 931-938, 2017.

38. Mosmann T: Rapid colorimetric assay for cellular growth and survival: Application to proliferation and cytotoxicity assays. J Immunol Methods 65: 55-63, 1983.

39. Perri F, Pacelli R, Della Vittoria Scarpati G, Cella L, Giuliano M, Caponigro F and Pepe S: Radioresistance in head and neck squamous cell carcinoma: Biological bases and therapeutic implications. Head Neck 37: 763-770, 2015.

40. Bussmann L, Busch CJ, Lörincz BB, Rieckmann T, Block A and Knecht R: Perspectives in chemosensitivity and chemoresistance assays and their implementation in head and neck cancer. Eur Arch Otorhinolaryngol 273: 4073-4080, 2016.

41. Riley JL: Combination checkpoint blockade-taking melanoma immunotherapy to the next level. N Engl J Med 369: 187-189, 2013.

42. Michot JM, Lazarovici J, Ghez D, Danu A, Fermé C, Bigorgne A, Ribrag V, Marabelle A and Aspeslagh S: Challenges and perspectives in the immunotherapy of Hodgkin lymphoma. Eur J Cancer 85: 67-77, 2017.

43. Mann JE, Hoesli R, Michmerhuizen NL, Devenport SN, Ludwig ML, Vandenberg TR, Matovina C, Jawad N, Mierzwa M, Shuman AG, et al: Surveilling the potential for precision medicine-driven PD-1/PD-L1-targeted therapy in HNSCC. J Cancer 8: 332-344, 2017.

44. Wood O, Clarke J, Woo J, Mirza AH, Woelk CH, Thomas GJ, Vijayanand P, King E and Ottensmeier $\mathrm{CH}$ : Head and neck squamous cell carcinomas are characterized by a stable immune signature within the primary tumor over time and space. Clin Cancer Res 23: 7641-7649, 2017.

45. Reya T, Morrison SJ, Clarke MF and Weissman IL: Stem cells, cancer, and cancer stem cells. Nature 414: 105-111, 2001.

46. Pardal R, Clarke MF and Morrison SJ: Applying the principles of stem-cell biology to cancer. Nat Rev Cancer 3: 895-902, 2003.

47. Hermann PC, Bhaskar S, Cioffi M and Heeschen C: Cancer stem cells in solid tumors. Semin Cancer Biol 20: 77-84, 2010.

48. Tehranchi R, Woll PS, Anderson K, Buza-Vidas N, Mizukami T, Mead AJ, Astrand-Grundström I, Strömbeck B, Horvat A, Ferry $\mathrm{H}$, et al: Persistent malignant stem cells in del(5q) myelodysplasia in remission. N Engl J Med 363: 1025-1037, 2010.

49. Creighton CJ, Li X, Landis M, Dixon JM, Neumeister VM, Sjolund A, Rimm DL, Wong H, Rodriguez A, Herschkowitz JI, et al: Residual breast cancers after conventional therapy display mesenchymal as well as tumor-initiating features. Proc Natl Acad Sci USA 106: 13820-13825, 2009.

50. Teng Y, Wang X, Wang Y and Ma D: Wnt/beta-catenin signaling regulates cancer stem cells in lung cancer A549 cells. Biochem Biophys Res Commun 392: 373-379, 2010.

51. Viale A, De Franco F, Orleth A, Cambiaghi V, Giuliani V, Bossi D, Ronchini C, Ronzoni S, Muradore I, Monestiroli S, et al: Cell-cycle restriction limits DNA damage and maintains self-renewal of leukaemia stem cells. Nature 457: 51-56, 2009.

52. Dean M: ABC transporters, drug resistance, and cancer stem cells. J Mammary Gland Biol Neoplasia 14: 3-9, 2009.

53. Kobune M, Takimoto R, Murase K, Iyama S, Sato T, Kikuchi S, Kawano Y, Miyanishi K, Sato Y, Niitsu Y and Kato J: Drug resistance is dramatically restored by hedgehog inhibitors in $\mathrm{CD} 34^{+}$ leukemic cells. Cancer Sci 100: 948-955, 2009.
54. Zhou Y, Zhou Y, Shingu T, Feng L, Chen Z, Ogasawara M, Keating MJ, Kondo S and Huang P: Metabolic alterations in highly tumorigenic glioblastoma cells: Preference for hypoxia and high dependency on glycolysis. J Biol Chem 286: 32843-32853, 2011.

55. Baumann M, Krause $M$ and Hill R: Exploring the role of cancer stem cells in radioresistance. Nat Rev Cancer 8: 545-554, 2008.

56. Lagadec C, Vlashi E, Della Donna L, Meng Y, Dekmezian C, Kim K and Pajonk F: Survival and self-renewing capacity of breast cancer initiating cells during fractionated radiation treatment. Breast Cancer Res 12: R13, 2010.

57. Wang Y: Effects of salinomycin on cancer stem cell in human lung adenocarcinoma A549 cells. Med Chem 7: 106-111, 2011.

58. Basu D, Montone KT, Wang LP, Gimotty PA, Hammond R, Diehl JA, Rustgi AK, Lee JT, Rasanen K, Weinstein GS and Herlyn M: Detecting and targeting mesenchymal-like subpopulations within squamous cell carcinomas. Cell Cycle 10: 2008-2016, 2011.

59. Fuchs D, Heinold A, Opelz G, Daniel V and Naujokat C: Salinomycin induces apoptosis and overcomes apoptosis resistance in human cancer cells. Biochem Biophys Res Commun 390: 743-749, 2009.

60. Fuchs D, Daniel V, Sadeghi M, Opelz G and Naujokat C: Salinomycin overcomes ABC transporter-mediated multidrug and apoptosis resistance in human leukemia stem cell-like KG-la cells. Biochem Biophys Res Commun 394: 1098-1104, 2010.

61. Zhang G, Wang W, Yao C, Ren J,Zhang S and Han M: Salinomycin overcomes radioresistance in nasopharyngeal carcinoma cells by inhibiting Nrf2 level and promoting ROS generation. Biomed Pharmacother 91: 147-154, 2017.

62. Zhang Y, Zuo Y, Guan Z, Lu W, Xu Z, Zhang H, Yang Y, Yang M, Zhu H and Chen X: Salinomycin radiosensitizes human nasopharyngeal carcinoma cell line CNE-2 to radiation. Tumour Biol 37: 305-311, 2016.

63. Ketola K, Hilvo M, Hyötyläinen T, Vuoristo A, Ruskeepää AL, Orešič M, Kallioniemi O and Iljin K: Salinomycin inhibits prostate cancer growth and migration via induction of oxidative stress. Br J Cancer 106: 99-106, 2012.

64. Kim JH, Yoo HI, Kang HS, Ro J and Yoon S: Salinomycin sensitizes antimitotic drugs-treated cancer cells by increasing apoptosis via the prevention of G2 arrest. Biochem Biophys Res Commun 418: 98-103, 2012.

65. Bortner CD, Hughes FM Jr and Cidlowski JA: A primary role for $\mathrm{K}^{+}$and $\mathrm{Na}^{+}$efflux in the activation of apoptosis. J Biol Chem 272: 32436-32442, 1997.

66. Scherzad A, Hackenberg S, Froelich K, Rak K, Hagen R, Taeger J, Bregenzer $\mathrm{M}$ and Kleinsasser N: Chronic exposure of low dose salinomycin inhibits MSC migration capability in vitro. Biomed Rep 4: 325-330, 2016.

67. Sun J, Luo Q, Liu L, Yang X, Zhu S and Song G: Salinomycin attenuates liver cancer stem cell motility by enhancing cell stiffness and increasing F-actin formation via the FAK-ERK1/2 signalling pathway. Toxicology 384: 1-10, 2017

68. Kopp F, Hermawan A, Oak PS, Herrmann A, Wagner E and Roidl A: Salinomycin treatment reduces metastatic tumor burden by hampering cancer cell migration. Mol Cancer 13: 16, 2014.

69. Scherzad A, Hackenberg S, Schramm C, Froelich K, Ginzkey C, Hagen R and Kleinsasser N: Geno- and cytotoxicity of salinomycin in human nasal mucosa and peripheral blood lymphocytes. Toxicol In Vitro 29: 813-818, 2015. 